\title{
WhatsApp Disruptions in Brazil: \\ A content analysis of user and news media responses, 2015-2018
}

\author{
Gabriel Pereira (Aarhus University), Iago Bojczuk (MIT), and Lisa Parks (MIT) \\ Preprint (Final Manuscript), article accepted for publication at Global Media \& \\ Communication
}

In 2015 a simple black-and-white drawing appeared in a tweet with the statement, "whatsapp will be blocked for 48 hours starting thursday at midnight" (Fig. 1). ${ }^{1}$ The drawing depicts a person in silhouette sitting against a wall and facing a vast, white, empty space. Brazilian WhatsApp users circulated this drawing as a meme, along with many others, upon facing the daunting prospect of a court-ordered WhatsApp shutdown. The meme parodically conveys the sense of disconnection and social alienation users felt during Brazil's WhatsApp shutdowns in 2015 and 2016, and speaks to WhatsApp's growing prominence in Brazilian media and communication practices.

whatsapp sera bloqueado por 48horas à partir da Oh de quinta-feira

๑ View translation

Fig. 1 - "whatsapp will be blocked for 48 hours starting thursday at midnight."

\footnotetext{
1 All memes and other texts written in Brazilian Portuguese have been translated by the authors, while keeping their original style of writing and capitalization.
} 
WhatsApp, ZapZap, or simply Zap, as it has been affectionately nicknamed by Brazilians, has a substantial user community in the country. Surveys show that over 120 million of the 210 million people in Brazil are active WhatsApp users (Estadão, 2017), and 93\% of Brazilian smartphone owners use the app daily (MobileTime, 2018). People use it to chat with friends and colleagues, or discuss issues with groups from school, church, and work. Brazilians also use WhatsApp to sell clothing, order pizza, book nail salon appointments, and check-in with doctors. In the southeastern city of Sorocaba citizens also use WhatsApp to report transit infractions by forwarding pictures of incidents to the city's Transportation Department hotline (Tomazela, 2018). WhatsApp use has become an integral part of everyday life in Brazil, and the country has seen creative and extensive adoption of the platform. ${ }^{2}$

Launched in 2009 as an alternative to SMS by former Yahoo employees, Brian Acton and Jan Koum, the platform has garnered one of the largest user communities in the world, with an impressive 1.5 billion monthly users (Constine, 2018). WhatsApp has been especially appealing in Brazil for various reasons, including its simple and accessible user interface, the country's historically insufficient telecom infrastructure, lower service fees for mobile internet, and the app's seamless overlay with mobile telephony. By treating every mobile phone number as a user and automatically adding a phone's contact list to the WhatsApp contacts, the app makes the transition between SMS and phone calls seamless. In Brazil, WhatsApp's emergence has enabled multimodal communication at a relatively low cost for a population whose access to digital technologies has historically been limited.

In 2016, WhatsApp made headlines by adding end-to-end encryption to all of its messaging services (Isaac, 2016) after Edward Snowden's revelations about the U.S. National Security Agency (NSA)'s mass surveillance programs. Santos \& Faure (2018) suggest, "as privacy and security within the digital realm become issues of public interest, they concomitantly become an attractive marketing idea" (p.2). WhatsApp adopted and promoted its encryption features to position "the company in a strategic way when facing legal dilemmas regarding privacy and security issues when and where national states, enforcement agencies or other actors try to coerce it to "collaborate"' (p.13), while also addressing users' growing concerns about digital privacy.

\footnotetext{
2 Throughout the article we refer to WhatsApp as an "app" and "platform." We use app to refer to the software used by the users on their mobile phone, while the term platform is applied to refer to the broader international infrastructure that makes the app's use and appropriation possible.
} 
In Brazil, WhatsApp's encryption of messages sparked controversies related to highly publicized drug trafficking cases, creating friction between government officials, WhatsApp users, law enforcers, and telecom companies (Teixeira et al, 2017). Public discussions of WhatsApp's encryption and other affordances have persisted in Brazil, and since 2016 the app has received intense criticism in the news media for facilitating the spread of false information, hate speech, and hoaxes. Such criticisms of WhatsApp have been particularly prominent in countries in the Global South. For instance, in 2017-2018 the app was linked to the spread of fake news in Kenya (Dahir, 2017), blamed for polarization and mob killings in India based on hoaxes involving so-called "child lifters" (Goel, 2018; see also Rodrigues, 2019), and has been associated with rumors about fatal reactions to yellow fever vaccines and toxic chemicals in Brazil (Molteni, 2018). In 2018, the discussion around illegal WhatsApp use during the Brazilian Presidential elections captivated national and international media attention as rightwing politician Jair Bolsonaro rose to power and became Brazil's 38th president.

Despite these scandals, critical media and communication scholarship has only recently begun to explore WhatsApp's growing influence on everyday life in countries of the Global South. Most relevant to the current study is research on the domestication of WhatsApp in Argentina (Matassi, Boczkowski, \& Mitchelstein, 2019), an analysis of Facebook and WhatsApp use in the small, low-income town of Balduíno, Brazil (Spyer, 2019), and a growing body of scholarship on WhatsApp's influential role in the 2018 Brazilian elections (Machado \& Konopacki, 2019; Resende et al, 2019ab; dos Santos, 2019). Beyond this, a special issue of First Monday provides insightful analyses of WhatsApp's social implications across diverse international contexts, focusing, for example, on the appropriation and use of the app in Mexico (Treré, 2020; Gómez Cruz \& Harindranath, 2020), Malaysia (Johns, 2020), and Brazil (Santos, Saldaña, \& Rosenberg, 2020; Milan \& Barbosa, 2020). As the editors explain, "WhatsApp as a technology and as a site of social practice requires further scholarly attention, and we hope to see more research on the platform in the years to come," (Baulch, Matamoros-Fernández, and Johns, 2020). These studies have initiated crucial scholarly discussions of WhatsApp within the cultural and political contexts of the Global South.

To extend critical understandings of WhatsApp usage in Brazil, this article explores the app's diverse and influential roles in the country from 2015-2018, a period in which national adoption rates increased dramatically. WhatsApp became a new kind of privatized media and communication infrastructure (Parks \& Starosielski, 2015) in Brazil and users grew increasingly reliant upon the platform and integrated it into everyday life. To explore Brazilians' intensifying everyday relationship to WhatsApp, we analyze user and news media 
responses to WhatsApp disruptions. During these moments, WhatsApp stopped functioning "as usual" and the platform became a site of public concern and discussion. Brazilians reflected upon their growing reliance on WhatsApp and experienced the platform in "new and sometimes surprising ways" (Jackson, 2015: 230). In these moments of disruption "the normally invisible quality of working infrastructure" became "visible" (Star \& Ruhleder, 1996: 113), and drew attention to operations that consumers/users often take for granted (see also Bowker \& Star, 1999; Parks, 2012; Sandvig, 2013).

To investigate these issues further, we develop two case studies based on different types of WhatsApp disruptions - a technical-legal shutdown and a socio-political breakdown-which occurred in Brazil between 2015 and 2018. The first case study focuses on four moments in 2015-2016 when Brazilian courts ordered technical shutdowns of WhatsApp services across the country, generating troves of Internet memes- "viral, user-generated media rapidly created, adapted, circulated, and consumed in online spaces" (Shifman, 2014). These memes made fun of Brazilians' everyday reliance on WhatsApp and revealed the platform had become an important media infrastructure in the country. The second case study focuses on a sociopolitical breakdown related to WhatsApp use during the 2018 Brazilian Presidential election. WhatsApp attracted mounting public criticism as political candidates and their supporters advanced campaigns via WhatsApp in new, controversial, and potentially illegal ways (i.e. 'fake news' and bulk messaging). We approach this disruption as a socio-political breakdownas a moment in which the platform became a site of public concern and inquiry. WhatsApp use was disrupted when media discourses constructed the platform as a "political battleground" and a "no man's land." In response, users grew increasingly suspicious of WhatsApp and some temporarily left the platform altogether.

To develop these two case studies, we use the methodology of content analysis and critically engage with Brazilian memes and news media coverage, which we translated from Portuguese to English. To conduct the first case study, we collected and reviewed 140 Internet memes curated and re-published by ten mainstream Brazilian media outlets with high levels of readership and online presence during and after the WhatsApp shutdowns (e.g. G1, Estadão, $U O L$, etc. .). ${ }^{3}$ After collecting and reviewing all of the memes, we recognized that all of them addressed the issue of growing cultural dependence on WhatsApp in Brazil in different ways, and we selected a series of examples for discussion and analysis. For the second case study, we gathered online news articles from five of Brazil's largest newspapers and three international

\footnotetext{
${ }^{3}$ For the full list, see Attachment 1.
} 
news outlets with wide circulation in the country. ${ }^{4}$ Our selection focused on the period leading up to and just after the 2018 Presidential elections and reveals how news media communicated about WhatsApp's role in Brazil's political processes and democracy. ${ }^{5}$

These two WhatsApp disruption case studies offer insights about the app's integration in cultures of everyday life in Brazil and suggest it has become a vital yet politically charged media and communication infrastructure in the country. By contextualizing different WhatsApp disruptions in Brazil, we demonstrate the challenges that countries of the Global South face when privatized U.S.-based "platform-based services acquire characteristics of infrastructure, while both new and existing infrastructures are built or reorganized on the logic of platforms" (Plantin et al, 2016). Often explained through theories of telecom privatization and neoliberal economics, apps or platforms developed and owned in the U.S. may, for various reasons, become infrastructural in Global South contexts, where different material conditions are present, including telecom precarity, affordability challenges, ease of adoption and use, and values placed on group communication (Aouragh \& Chakravartty, 2016).

\section{Contextualizing WhatsApp in Brazil}

Brazil is far from having a technology-based economy, but the country's IT sector has boomed between 2000 and 2011 (de Oliveira, 2016; Talamoni \& Galina, 2014). This industrial expansion, coupled with increased consumer interest in acquiring personal computers resulted in government programs that supported the development of telecenters and LAN (Local Area Network) houses (Lemos \& Martini, 2010). These initiatives led to expanded Internet access in Brazil and the formation of digital cultures beyond middle-class households, reaching even marginalized places such as favelas, urban slums in Brazil, that have historically been deprived of physical investments and access to IT (Nemer, 2016). Beyond this, a substantial number of working-class Brazilians self-financed their digital integration by purchasing smartphones and data plans (Spyer, 2017). As Internet access and digital technologies moved across multiple socioeconomic strata at a rapid pace, Brazil experienced dramatic growth in the smartphone industry, the emergence of mobile Internet services, and participation in social media platforms in the 2010s.

\footnotetext{
${ }^{4}$ The five national newspapers are Estadão, Gazeta do Povo, Folha de S. Paulo, UOL and G1; the three global newspapers are El Pais Brasil, BBC Brasil, and The New York Times. All of the articles were written by Brazilian correspondents and published in Brazilian Portuguese.

${ }^{5}$ It is important to highlight that our analysis is based on discourses in circulation in the news media, and not on actual individuals' sentiments towards the platform.
} 
If a decade ago being on the Internet in Brazil meant being on a now-extinct social networking website operated by Google called Orkut (Recuero, 2009), today Facebook and WhatsApp have become the platforms of preference among users (Spyer, 2017: 36). These platforms are significant among all socioeconomic demographics and geographical regions of Brazil with $59 \%$ of the population having Facebook accounts and $66 \%$ using WhatsApp (Latinobarómetro, 2018: 78). Moreover, Brazil often ranks among the top global users of these services. One may not have an email account or online banking access, but WhatsApp is likely to be part of daily activities, whether socializing with friends in groups, making calls, or sharing content and news stories. Before WhatsApp's emergence in Brazil, digital media practices were confined to desktop computers connected to broadband Internet, where users interfaced via Google Orkut and Microsoft MSN Messenger. As Spyer (2017: 36) contends, Facebook and WhatsApp have been widely adopted not only because they offer "technical and design advantages over these predecessors," but because their "core characteristics ... resemble those of Orkut and [MSN] Messenger."

In fact, Brazil's IT adopters have an intriguing history of quickly appropriating digital media technologies from the Global North and inscribing them with local cultural values, as in the case of Orkut starting in 2006. In her analysis of Brazil's adoption of digital media technologies, Heather Horst (2011) suggests three core values captured the country's new media landscape: free culture, digital inclusion, and networked sociality. The interplay of these concepts, Horst argues, is evident in the ways Brazilians have transformed "processes of production, distribution, and consumption" of digital content (Horst, 2011: 454). That is, the unique histories, places, and cultures of Brazilians directly shaped user experiences with technologies and platforms designed and built outside the country. While Horst's conceptualization of these three values was grounded in new media practices of the time (e.g. microblogging, music streaming, online communities), these values remain highly relevant to a critical analysis of WhatsApp's role in Brazil. The platform has become a domain in which those core values and digital media practices collide: it is "free," easy to use, and allows for varied types of mediated social experiences through visual texts, voice and video calls, and group discussion.

Although WhatsApp has become integral to Brazilians' digital media and communication and has been appropriated for diverse and creative cultural uses, questions of affordability persist. To a large extent, the great appeal of WhatsApp among Brazilian users is connected to the fact that the services of state and private telecom providers have historically been costly and inaccessible to many low-income users. By turning a Silicon Valley-based app 
into a kind of national telecom system or digital media infrastructure, Brazilian users bypass unaffordable messaging services offered by mobile carriers in favor of WhatsApp. As in other Global South countries that lack telecom infrastructure and competitive market share, WhatsApp adoption in Brazil exemplifies how users may seize upon an app and transform it to serve local needs and interests. In such scenarios users may leapfrog the services of state telecom providers, which may not offer the kind of affordable, user-friendly, and secure services that consumers desire and demand.

While mobile providers' SMS services were prohibitively expensive for many in Brazil, Internet penetration, especially of mobile Internet, has grown significantly over the past decade. Socio-economic and digital inequalities exist throughout the country and have intensified due to a recession of historical proportions that sparked significant concern mostly between 20142017, a period marked by President Dilma Rousseff's removal from office due to a controversial and politically-charged impeachment process. Despite this, Brazil's 2017 Internet exposure rate was relatively high, with $67.47 \%$ of the population accessing the Internet. In 2007 that percentage was nearly $30 \%$, compared to only $2.87 \%$ in 2000 (ITU, 2018b). The country shows a different pattern from developed countries in high-speed Internet access. Given high service fees (Jensen, 2011), fixed broadband subscriptions include only 13.69\% of Brazilians, whereas that rate is $33.85 \%$ in the United States (World Bank, 2019). Mobile Internet in Brazil, on the other hand, is particularly inexpensive, figuring as the 4th cheapest in the world in 2017 (Telebrasil, 2017). ${ }^{6}$ Brazilian users are among the savviest smartphone app downloaders in the world (ITU, 2018a: 77), and have an increasingly voracious appetite for new data/tech products and services. For example, between 2014 and 2016 alone, revenues for apps increased by 70 percent in the country (ITU, 2018a: 77).

The smartphone industry largely drives the rapid growth of high-speed Internet service in Brazil. The more smartphones in use, the more need there is for a telecom infrastructure to connect these devices to the global Internet. In Brazil, there are about 220 million smartphones, roughly more than one device per inhabitant (Meirelles, 2018). ${ }^{7}$ The country's 3G mobile internet coverage has been relatively stable since 2014 and is now available to $99.5 \%$ of the population (Telebrasil, 2019). The rise of 4G, however, promises to make smartphone and mobile internet use even more prominent throughout the country. In 2014 only 147 Brazilian

\footnotetext{
${ }^{6}$ In relation to WhatsApp's growth, it is important to underscore that many of Brazil's mobile data plans come with a free use quota of WhatsApp and Facebook data, adapting their business models in order to attract more clients.

${ }^{7}$ If notebook and tablets are counted, that number would rise to 306 million mobile devices, which results in 1.5 portable device(s) per person (ibid).
} 
cities had 4G coverage, but in 2018 that number skyrocketed to 4,429, meaning that $95 \%$ of the recognized cities benefits from $4 \mathrm{G}$ coverage (ibid). In a country as large as Brazil, such conditions reflect the government's engagement with the private sector in revamping ICT infrastructure over the last decade.

The upgrading of the mobile Internet services sector from $3 \mathrm{G}$ to $4 \mathrm{G}$, the high saturation of smartphones, users' avid downloading of new apps and platforms, and their commitment to pre-existing values in their digital media practices, help to explain WhatsApp's quick adoption and popularization in Brazil. Furthermore, WhatsApp represents a shift in Brazil's media landscape as companies continue to expand broadband networks and cheap mobile Internet, in an effort to allow seamless connection to and usability of the app to users all over the country. Given that apps and platforms are swiftly adopted by users across regions with unique histories, cultures, socioeconomic conditions, and infrastructures, it is imperative to closely analyze local/national uses of those emergent technologies as well as the discourses surrounding them. If the context of Brazilian telecommunications helps explain the rise of WhatsApp, responses to the platform's disruptions reveal that it became understood and experienced as an everyday infrastructure.

\section{Disruption \#1: The WhatsApp Technical Shutdowns of 2015-2016}

In 2015 and 2016, state-level judges issued court orders mandating the immediate shutdown of WhatsApp in Brazil due to four unrelated cases. These cases involved the data logs of pedophilia suspects, drug trafficking, and other undisclosed crimes. During each of these cases, judges ordered that no user with a Brazilian IP address could access any WhatsApp services for a period of 48 to 72 hours. The app's suspension never lasted for the defined period of time because higher-ranking courts overruled these decisions. However, these orders reflect the government's growing concern about regulating WhatsApp in Brazil given the app's use for an array of legal and illegal activities. These shutdowns happened relatively unannounced, leaving users feeling dismayed and disconnected. A survey by Santos, Saldaña, \& Rosenberg (2020) found that the shutdown "generated important levels of anger, isolation, and anxiety in the population."

As users struggled to understand the situation and the court's legal rationale, they flocked to other platforms-such as Twitter, Facebook, and Telegram-in acts of "platform jumping"-that is, "users tactically shift[ed] their practices of sharing or consuming information from one platform to another in an effort to facilitate broader access to that 
information" (Parks \& Mukherjee, 2017). As users found ways to re-establish daily practices of communication on other platforms, they shared funny memes and commentaries about the WhatsApp shutdowns. These memes used irony, parody, and a creative collage of videos, images, and texts to expose users' growing reliance on WhatsApp.

Similar to events such as the 2014 World Cup and the 2016 impeachment of Brazil's President Dilma Rousseff, journalists from the major newsrooms in the country, such as Globo and Estadão, reported on the most circulated shutdown memes. Situating them in relation to other more serious reporting of these events, the news media published articles with titles such as "Internet Users go Crazy with WhatsApp Shut Down and Create Funny Memes" (“Internautas vão à loucura com bloqueio do WhatsApp e criam memes divertidos," R7, 2016) and "Justice Blocks WhatsApp and the Internet Responds with Memes" ("Justiça Manda Bloquear WhatsApp, e Internet Responde com Memes,” G1, 2016).

Brazil's WhatsApp shutdown memes exemplified a recurring use of hyperbole to describe feelings of suffering, drift, solitude, and surprise. Some memes focused on tropes of isolation and disconnection in a tone of self-parody. A consistent popular media reference in shutdown memes was the Hollywood movie, Cast Away (2000), which features a character, played by actor Tom Hanks, stranded on an uninhabited island after a plane crash. The character attempts to survive far away from civilization, making do with limited resources. Two sample Twitter posts (Figs. 2 and 3) feature minimal words ("me without whatsapp" and "A few hours without Whatsapp"), but are presented alongside images from the movie. They compare life without WhatsApp to life as a castaway on a deserted island. These posts had hundreds of comments and re-tweets, and generated varied responses across platforms, spreading the idea that the WhatsApp disruption brought about primitive conditions and isolated individuals from the digital world. 


\section{eu sem whatsapp}

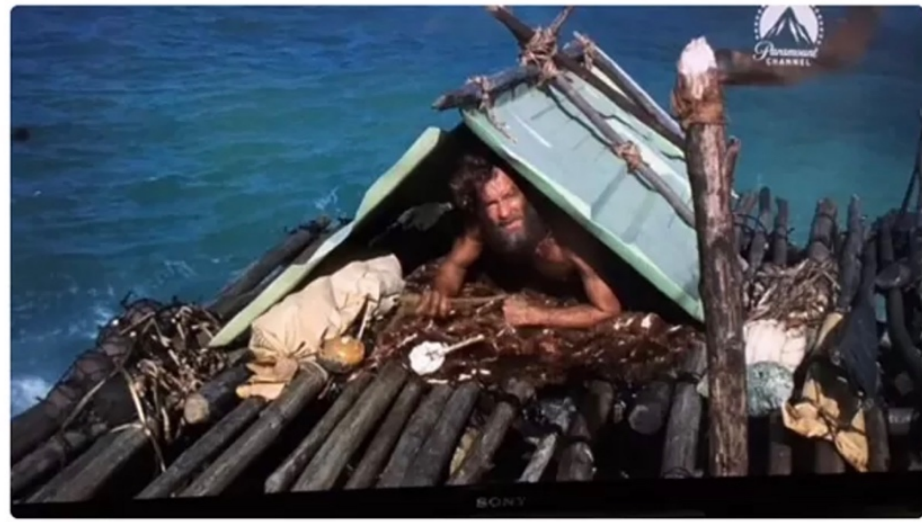

RETWEETS CURTIDAS

103

MEDB I

19:05 - 16 de dez de 2015

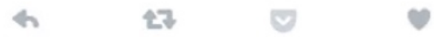

Usuário virou 'O náufrago' de Tom Hanks após noticia do bloqueio do WhatsApp no Brasil (Foto: Reprodução/Twitter/@euidiotices)

Fig. 2 - "me without whatsapp" (picked up by G1). It is accompanied by a caption by the journalist that selected it, which reiterates how the user that created the meme became a "cast away", like Tom Hanks, after the WhatsApp shutdown.

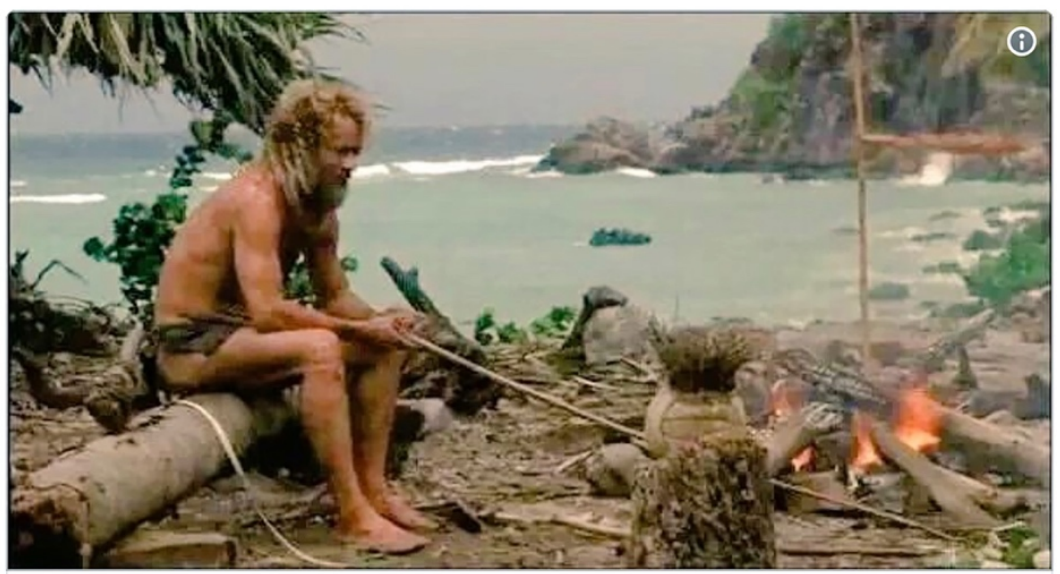

Frases

@Privacidades

Algumas horas sem o Whatsapp

O 540 10:22 AM - Jul 19, 2016

Q 395 people are talking about this

$>$

Fig. 3 - "A few hours without Whatsapp" (picked up by Catraca Livre). 
Brazilian users' feelings about the platform are encapsulated in a tweet from Priest Fabio de Melo, a famous Brazilian with nearly 6 million followers, who wrote: "WhatsApp is that friend who we find a bit annoying, but think it's bad when they become absent." ["O WhatsApp é aquele amigo que a gente acha chatinho, mas acha ruim quando ele se ausenta.']. Here, WhatsApp is not solely a messaging app; it is likened to a friendship that becomes most noticeable when it is gone. This idea that the app is essential for human existence is often framed in online discourse as an addiction. For instance, Fig. 4 features an image of an inconsolable man, with a hand to his chest, being embraced by family members attempting to comfort him. The meme's text overlay reads: "Is this serious? 48 hours without WhatsApp." The caption pushes the idea of addiction further by stating, "Be ready for the abstinence crisis of whatsapp lol\#Whatsapp." The idea of WhatsApp abstinence became a common theme during the shutdown as WhatsApp use was re-imagined as a compulsion or irresistible habit.

Other memes suggested Brazilians would likely become much more productive at work because of the shutdown. One of these memes shows the image of a resume with the caption "What am I gonna do without whatsapp?" (Fig. 5), conveying the idea that not having the app means more time to do "productive" things. Such memes implied WhatsApp and the sociality it enables take too much of people's time. Although these memes are excessive and hyperbolic in their commentaries about the shutdown, users created and circulated them to make sense of WhatsApp's intensifying impacts on everyday life in Brazil. These memes particularly emphasized issues of disconnection, dependence, and the freeing up of time to do other things during the shutdown. 


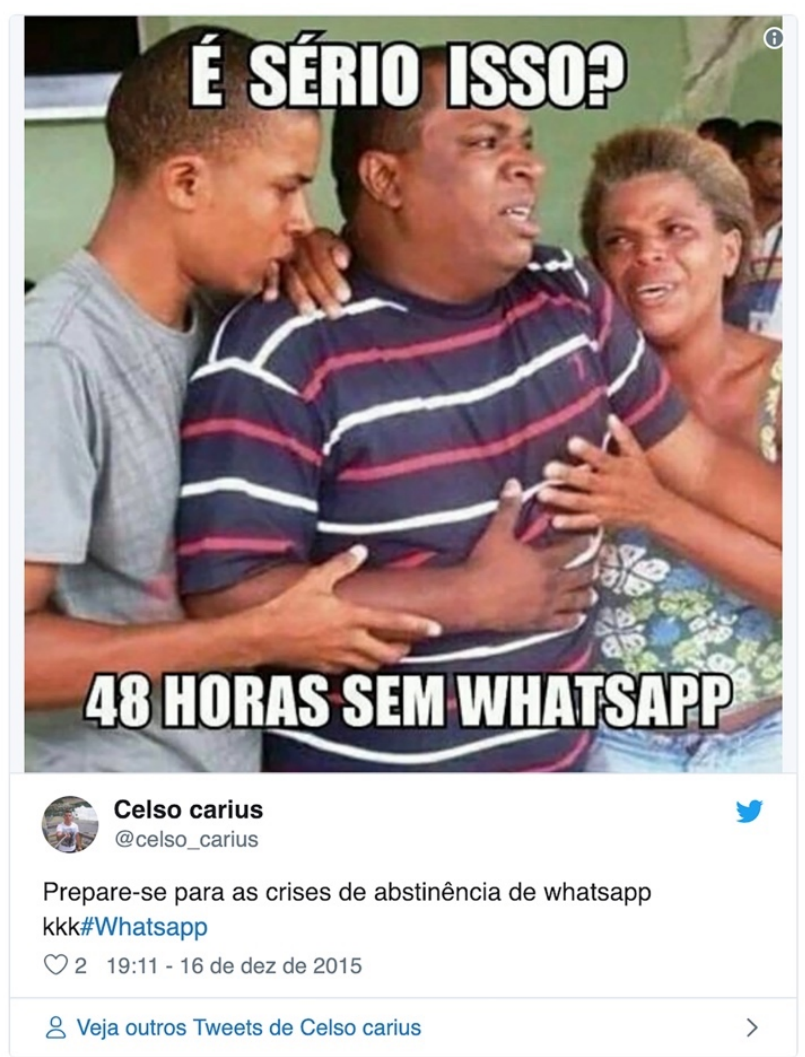

Fig. 4 - "Is this serious? 48 hours without WhatsApp" is the text on top of an image of an inconsolable man being embraced by family members that attempt to comfort him. The caption says: "Be ready for the abstinence crisis of whatsapp lol\#Whatsapp".

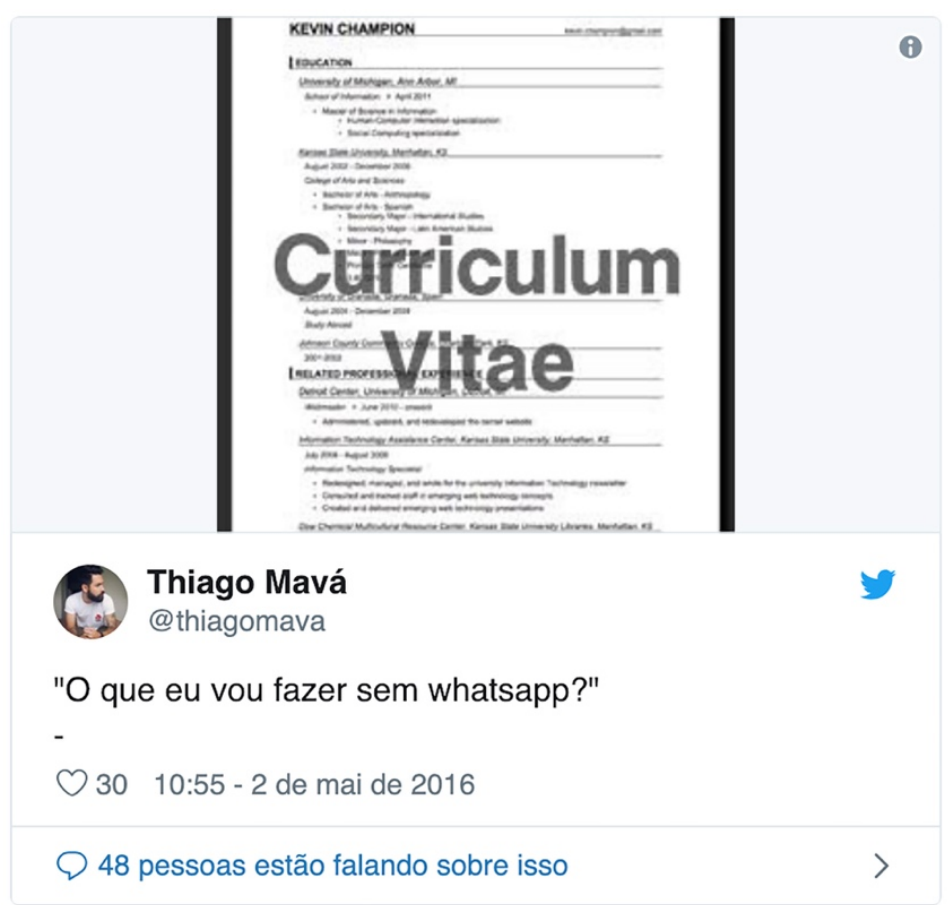

Fig. 5 - The image of a CV is shared with the caption "What am I gonna do without whatsapp?". 
While some of the WhatsApp shutdown memes emphasized user isolation and dependency, others invoked a hypothetical return to earlier communication technologies. Shutdown memes often included references to letters, pagers, telegraphy, old cellphones, cave drawings, smoke signals, carrier pigeons, and MSN messenger. One meme shows a person laying on a street curb, speaking on a falling down payphone with the caption, "Me speaking with my friends without WhatsApp" (Fig. 6). The meme plays on the absurdity of a return to near obsolete payphone technology. Another meme features a drawing of a typewriter with the phrase, "Due to the blocking, the Brazilian government developed this super technology to substitute WhatsApp" (Fig. 7). The paper on the typewriter reads, "Good morning family," suggesting that WhatsApp family groups can continue to communicate during the shutdown by articulating their expressions via an old typewriter. These memes point to earlier possibilities of technical mediation and stress how the WhatsApp shutdown compelled users to temporarily return to what are understood to be antiquated or "dead media." The idea of technological regression captured in these memes-that is, the return to a pre-digital erapresented opportunities for collective self-reflection about the past, present, and future of communication technologies in Brazil, but also tended to suppress public deliberation of the underlying reasons and people responsible for the shutdown.

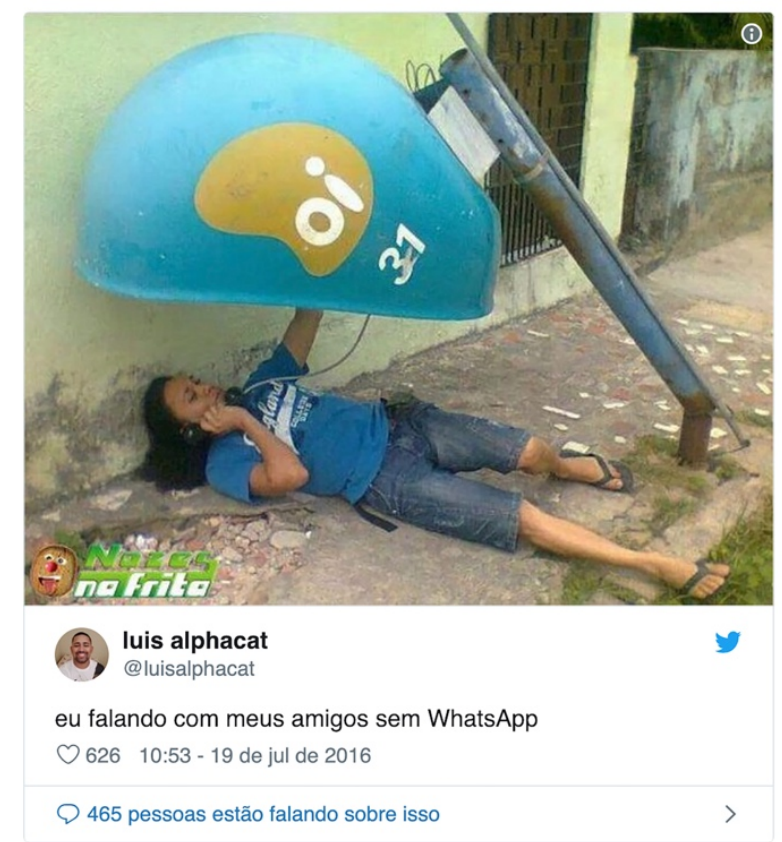

Fig. 6 - "Me speaking with my friends without WhatsApp," alongside a person weirdly talking on a payphone, showing how the lack of the app means regressing to obsolete practices. 


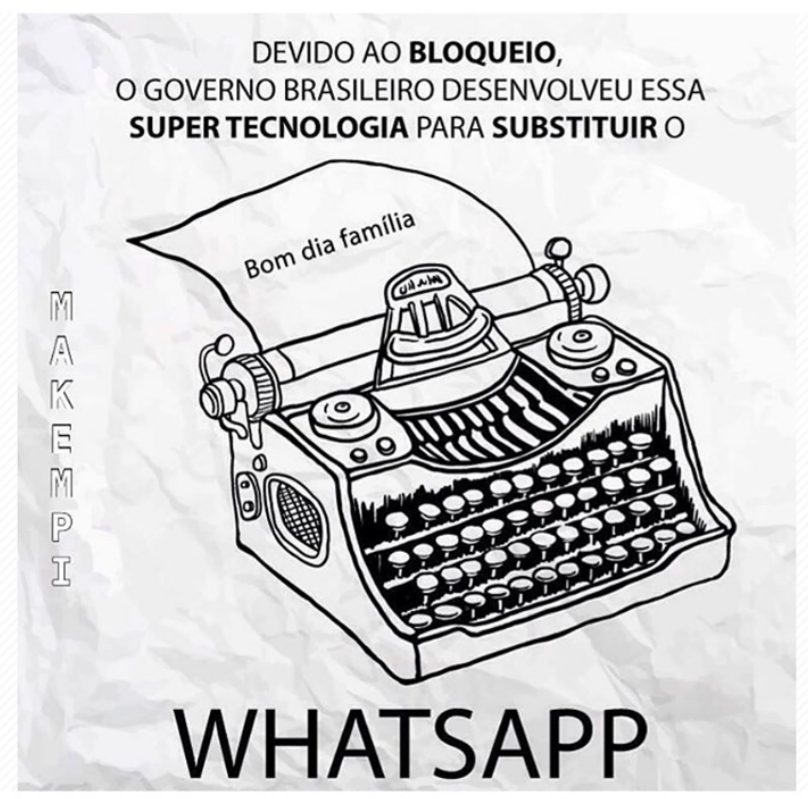

\section{f}

Fig. 7 - "Due to the blocking, the Brazilian government developed this super technology to substitute WhatsApp."

These memes ultimately position WhatsApp both as an inadequate alternative to and as a "descendant" of earlier technologies and cultural practices. One meme, for instance, shared on Twitter and published in the news outlet, Gazeta do Povo, features an image of cave drawings that mimic some of the most popular WhatsApp emojis. The caption says, "Testing this alternative to whatsapp" (Fig. 6). This meme is provocative in its ironic comparison of cave drawings and digital emoji culture. While the return to cave drawings conveys frustration with the shutdown, the meme also challenged online communities to recognize continuities between earlier iconographic forms of communication and contemporary digital emojis as part of a broader media history in Brazil and beyond. 


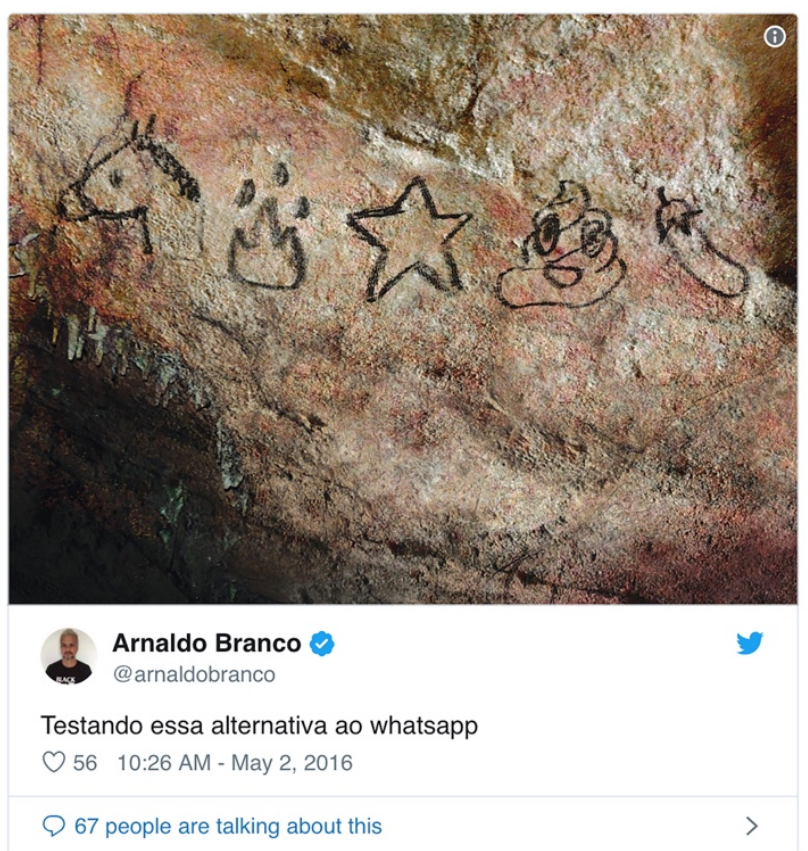

Fig. 8 - The user shares an image of what looks like cave drawings of WhatsApp's emojis, alongside the caption "Testing this alternative to whatsapp".

In addition to invoking earlier forms of communication, some shutdown memes encouraged the use of Telegram Messenger, a cloud-based instant messaging and voice over IP service created by the founders of VK, a Russian online social network. Since the shutdown surprised users who relied on WhatsApp, people quickly flocked to other services and Telegram use increased dramatically. During three hours of a 2015 WhatsApp shutdown more than 500,000 Brazilian users downloaded the app (G1, 2015). Memes did not speak to the differences between the apps; instead, they comically imagined Telegram employees' celebratory reactions to the WhatsApp shutdown as it provided them with more market share (Fig. 9). Such memes productively point out that, while Brazilian users may have felt their lives disrupted by the shutdown, corporate entities elsewhere were profiting from the situation by offering alternative platforms. 


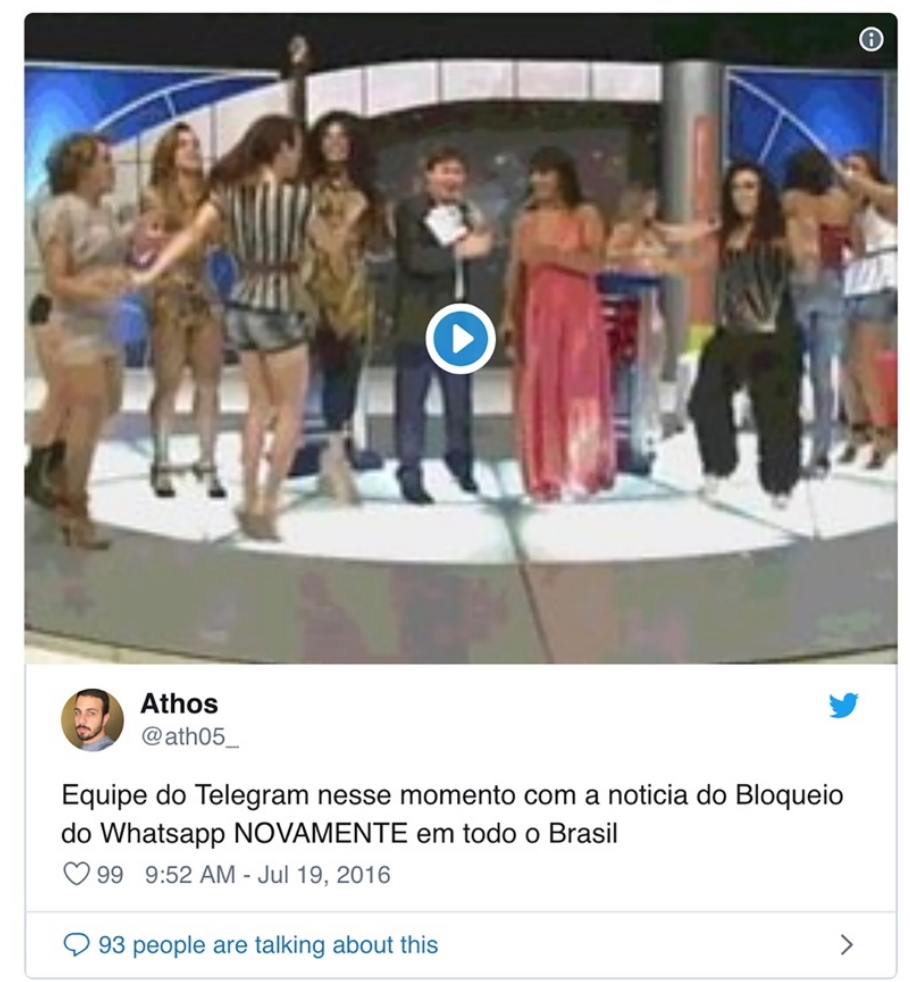

Fig. 9 - GIFs such as these were shared on Twitter, representing the "Telegram staff at this moment with the news of WhatsApp being shut down again in all of Brazil." In the moving image, people dance and jump as a commemoration.

During WhatsApp shutdowns in Brazil in 2015 and 2016 users created and circulated Internet memes that commented on the app's role in their everyday lives and communication practices, and reflected on its relation to a broader history of media technologies and cultures. The content of these Internet memes reveals that Brazilian users were beginning to imagine WhatsApp not just as another software download, but rather as an infrastructure of everyday life. Living without it brought forth feelings of isolation and dependency, and prompted users to consider WhatsApp's continuities with and differences from earlier technologies. The shutdown also pushed many Brazilian users to download and temporarily try alternative platforms.

After the Brazilian government's shut down of WhatsApp, Facebook's CEO Mark Zuckerberg (2016) acknowledged both that "Brazilians have been leaders in connecting the world and creating an open Internet for many years," and that denying people "the freedom to communicate the way they want is very scary in a democracy." Scholars, journalists, and civil society organizations must be equally wary about the ownership of platforms like WhatsApp, which allows U.S.-based parent company, Facebook, to penetrate and control markets around 
the world and, in the process, to shape global media and communication practices. It is not only a question of connectivity or freedom to communicate, then; it is also a question of who gets to regulate or control those platforms and the services they promise.

\section{Disruption \#2: The social breakdown of WhatsApp during Brazil's 2018 Elections}

If the 2015-2016 WhatsApp shutdowns exposed Brazilian users' widespread adoption and growing reliance on the app as a kind of national communication infrastructure, our second disruption case study concerns the app's exploitation during Brazil's 2018 elections. We refer to this disruption as a social breakdown because users who had come to rely on WhatsApp daily for news, information, and communication suddenly did not know which information they could trust. During the first and second voting sessions in September and October 2018, WhatsApp became understood as a haven of political influence and manipulation. The app became the focus of various political scandals and generated mounting criticism in the news media. In this section we analyze news media content regarding two scandalous practices enabled by WhatsApp-fake news and bulk messaging-and explore how these practices impacted the 2018 Brazilian elections, and elicited serious concerns among Brazilian citizens, policymakers, journalists, and scholars. In 2018, Brazilian news media commentaries on WhatsApp shifted dramatically: the app went from being imagined as a reliable communication infrastructure to a "no man's land," tainted by political corruption.

The 2018 election cycle in Brazil yielded intense national discussion and increased political polarization. In the context of heightened social and political fragmentation, campaigns used all means of communication possible to distribute messages. News media tracked and commented on the political uses of emergent technologies, including WhatsApp, pointing to innovative practices and questioning illegal/irregular ones. Patricia de Campos Mello, award-winning reporter with Folha de S. Paulo, explained in an interview (2019a) that she felt especially concerned about how WhatsApp could be deployed during the Brazilian elections, as social media platforms had been used to influence other elections around the world. For instance, Modi in India relied on Twitter (Baishya, 2015), and Trump in the U.S. appropriated Facebook with the help of Cambridge Analytica and Russian interference operatives (Vaidhyanathan, 2018; Jamieson, 2018). Given WhatsApp's embeddedness in Brazilian everyday life, establishing communication with voters through the app would be key to political campaigns' success (Campos Mello, 2019a). Accordingly, political operatives and 
marketing agencies anticipated that 2018 would be the "WhatsApp elections" in Brazil, similar to conditions in Malaysia described by Johns (2020).

Relatively early in Brazil's 2018 election cycle, the circulation of fake news became the first major WhatsApp scandal. Fake news, as a concept, is "used by fundamentally different and, in many ways deeply opposing political projects, as a means of constructing political identities, conflicts and antagonisms" (Farkas \& Schou, 2018). Allcott and Gentzkow suggest that fake news and social media were already pressing concerns during the 2016 U.S. elections, as people were "more likely to believe ideologically aligned headlines, and this ideologically aligned inference is substantially stronger for people with ideologically segregated social media networks" (2017, p.213). While in the U.S. fake news was largely associated with Facebook, in Brazil it was circulated primarily via WhatsApp. In the aftermath of the 2016 U.S. Presidential elections, Facebook received heavy criticism and implemented policies regarding sponsored content, content moderation, and fact-checking in an attempt to restructure its platform (Harbath, 2018). Though it is owned by Facebook, WhatsApp did not follow suit and did nothing to promote any type of formal content moderation. Instead, WhatsApp's spokespersons frequently justify existing services by emphasizing the end-to-end encryption and privacy that are crucial to the product's success.

Misinformation has been shown to spread "farther, faster, deeper, and more broadly than the truth" (Vosoughi et al, 2018), not only due to the actions of automated agents, or "bots," but also, some argue, because of human attraction to the sensational and the absurd. The limited digital and news media literacy in Brazil, and elsewhere, has also been associated with the sharing of false information through WhatsApp. In the period analyzed, fake news content circulated involving such issues as: the national electoral process; a candidate's participation in immoral or illegal issues (e.g. support to children's books that supposedly incentivize pedophilia); and campaign support from well-known Internet and TV celebrities. One of the most absurd examples was the black and white photo of former president Dilma Rousseff with the Cuban communist revolutionary Fidel Castro (Fig.10). This fabricated image was one of the most circulated on the 347 WhatsApp groups followed by Brazilian researchers from August $16^{\text {th }}$ to October $7^{\text {th }} 2018$, and was shared 78 times in the tracked public groups (Folha, 2018a). ${ }^{8}$ Although Dilma was not a presidential candidate, the objective of this false

\footnotetext{
${ }^{8}$ Ascertaining details about shared content on WhatsApp is difficult. In addition to encrypting messages, WhatsApp groups are most often set to private, making it virtually impossible to collect data unless one is part of it. This makes it impossible to quantitatively measure how widely a message circulates from one user or group to others.
} 
affiliation with Castro was to align her and her party with socialist ideologies that were constantly demonized by right-wing conservative Bolsonaro and his supporters.

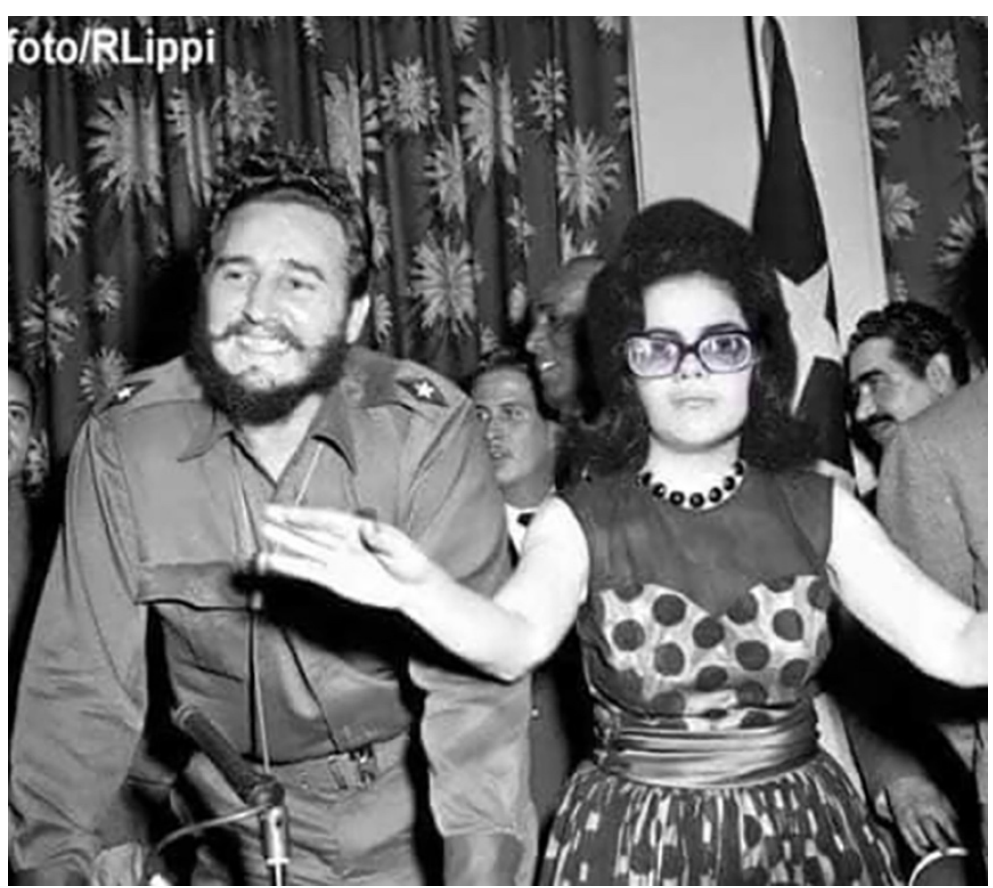

Fig. 10 - A fabricated image of former president Dilma Rousseff alongside Fidel Castro was widely shared on WhatsApp groups during the election period, used alongside different captions to incite the growing polarization.

As suggested earlier, rather than using WhatsApp as a peer-to-peer messaging app, Brazilians have appropriated the app as a platform for private, semi-private, and public groups-spaces where they chat and share information with family, co-workers, church friends, and other affiliates. There are also WhatsApp groups for discussing politics, social activism, religion, dating, and other issues. During the 2018 Presidential election the spread of fake news was articulated with these WhatsApp grouping practices. Political candidates and supporters shared WhatsApp links on other platforms and invited people to join these active groups. Once created, these groups became popular spaces for disseminating political content of multiple forms to known and unknown contacts. The groups shared media such as audio, pictures, videos, GIFs, and the recently created form called "stickers." The proliferating WhatsApp groups, combined with the app's decentralized, encrypted, and unmoderated structure, contributed to the flow of fake news in Brazil. ${ }^{9}$

\footnotetext{
${ }^{9}$ Although present throughout the ideological spectrum, Bolsonaro and his supporters were the front-runners in social media engagement. Apart from the social support to the candidate, this was possible because his
} 
As the fake news scandals unfolded in Brazil, journalistic commentaries on WhatsApp flourished. Some of the reports concentrated on the debunking of fake news stories, with headlines such as, "It is false the information of poster saying [Fernando] Haddad would legalize pedophilia" [É Falsa Informação de Cartaz Sugerindo Que Haddad Vai Legalizar Pedofilia] (Resende, 2018) and "It's \#FAKE the message that says that Bolsonaro simulated being stabbed to disguise cancer" ["É \#FAKE mensagem que diz que Bolsonaro simulou ser vítima de facada para disfarçar câncer"] (Domingos, 2018). ${ }^{10}$ As these headlines suggest, fake news compelled a public vetting process as journalists wrote more and more articles exposing these false stories and their absurdity.

While some reporters exposed online falsehoods, other journalistic coverage focused on state investigations and court orders related to fake news. Reports indicated that on October $20^{\text {th }}, 2018$ the Federal Police were ordered to investigate the sharing of fake news (de Souza \& de Carvalho, 2018), and that PSOL, a socialist left-wing party, had asked Brazil's Superior Electoral Court (TSE) to demand WhatsApp restrict all message forwarding, a request that was later rejected (Moraes Moura \& Pupo, 2018). As Brazilian news media devoted increased attention to these scandals, users felt a growing unease as it seemed fake news was taking over WhatsApp. It was not only challenging for users to parse the true from the false, but the stakes were very high given that much of the questionable information circulating via WhatsApp was related to candidates and their campaigns. Because of this, WhatsApp came to take on more sinister and problematic associations; it was characterized in the Brazilian press as a "No man's land," an "Underworld," and a "Deep Web."" Although no news reports could prove how extensive fake news stories were in their reach, there emerged a general sense that WhatsApp had become a communication space without control or regulation. Fake news was, according to news media rhetoric, "poisoning" Brazilian political life (Tardáguila, Benevenuto, \& Ortellado, 2018), and WhatsApp had become the "fertile ground" for its flourishing (Gragnani, 2018).

electorate had deployed WhatsApp as part of their strategy to win even prior to the election, managing a large number of groups for political discussions and media exchanges. As Nemer (2018) has reported, false information travelled from small groups of content-creators (producers), to regional and local Bolsonaro activists (bolsominions), to the everyday publics (family groups, classroom groups, neighborhood and others).

${ }^{10}$ Many newspapers and independent organizations set up fact checking services that acted to verify information that were being shared on WhatsApp. Amongst them, there were large interorganizational collaborations between many of the largest newspapers of the country (e.g. Comprova) and other smaller projects. Estadão Verifica, a service created by one of the largest newspapers in Brazil, received over 107 thousand messages in its WhatsApp hotline from people asking it to verify information (Monnerat, 2018).

${ }^{11}$ See Attachment 3 for this and other references. 
The second major scandal to shift news media discourse on WhatsApp during the 2018 elections involved "bulk messaging," the practice of frequently sending messages to a large group of people by employing automated scripts or cheap labor. The largest election scandal broke out on October 18, 2018, during the second round of the election campaigns. Private companies were reportedly illegally funding bulk messaging of political messages to WhatsApp users (Campos Mello, 2018b). What set this scheme apart from a simple act of spam was Brazilian campaigns' and marketing agencies' opportunistic infiltration of the group function of WhatsApp. Since bulk messages were regularly sent to groups and not to individuals, they often did not seem particularly suspicious, as users typically do not know all other individuals in their WhatsApp groups. Furthermore, these messages did not appear very different from others already in circulation, and thus ended up being disguised by the already large flow of messages. Yet a Brazilian independent research center, InternetLab, collected some of these messages and found that their content and ideology varied significantly, and ranged from candidate slogans to more complex memes, "chain mail," and messages that incited polarization (Cruz, Massaro, \& Borges, 2019; see Figs. 11-12).

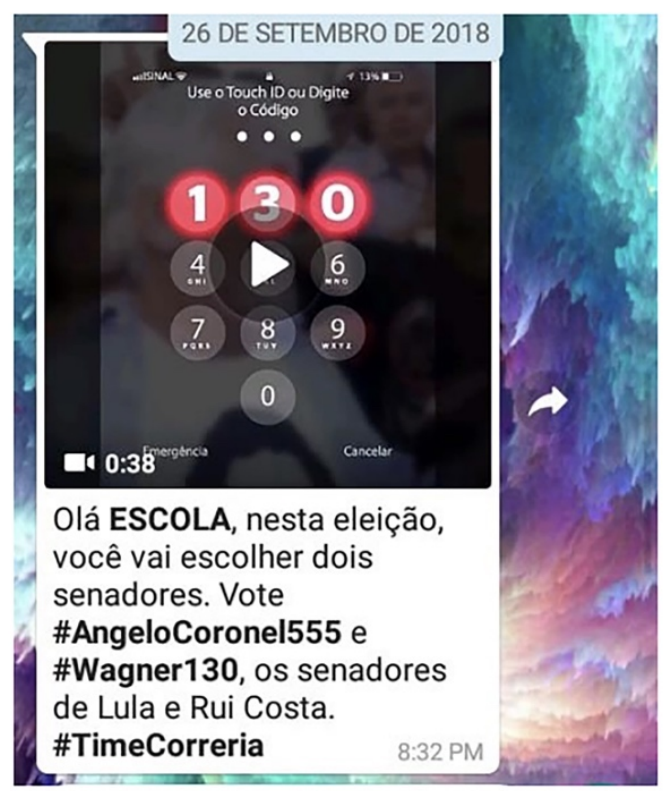

Fig. 11 - Example of spam message received by users, collected by InternetLab researchers: a video showing how to vote for two candidates (senator and governor). (image source: Cruz, Massaro, \& Borges, 2019) 


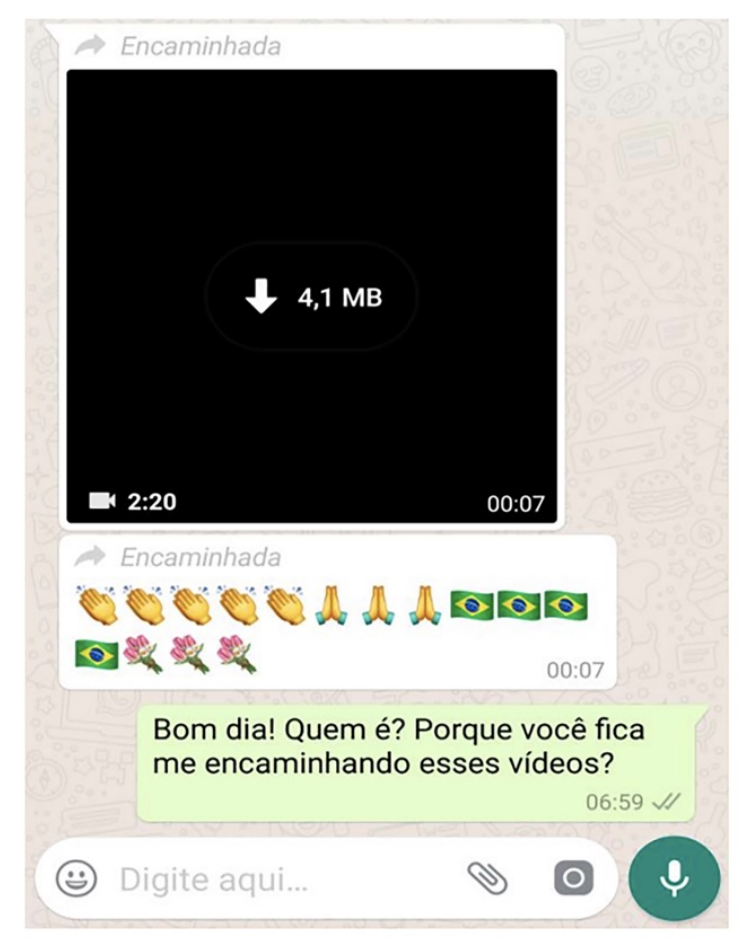

Fig. 12 - Example of spam message received by users, collected by InternetLab researchers: a political video and different emojis. The message receiver replies, "Good morning. Who is this? Why are you forwarding me these videos?" (image source: Cruz, Massaro, \& Borges,

Campos Mello broke the news story about political campaigns' use of bulk messaging in the largest Brazilian newspaper, Folha de S. Paulo, which has a daily circulation of 330,000 (Folha, 2019). Based on extensive interviews with marketing agencies involved in the scheme and those agencies' internal documents, Mello's story described the bulk messaging strategy by Bolsonaro's campaign supporters in great detail (Mello, 2018ab). She revealed that Brazilian marketing agencies supposedly used stolen CPF [social security] numbers to acquire SIM cards and used illegal automated messaging applications or hired Brazilian laborers to send bulk messages via WhatsApp, especially during the week leading to the final voting round. ${ }^{12}$ Researchers from the Institute for Technology \& Society of Rio (ITS-Rio) later supplemented the investigation and confirmed, "there are strong elements of the use of automation to power the distribution of information among different groups on WhatsApp" (Machado \& Konopacki, 2019).

\footnotetext{
${ }^{12}$ It was later suggested that Brazilian companies were also purchasing bulk messaging software from Spain, in order to evade scrutiny from electoral funding investigations. (Campos Mello, 2019b)
} 
Campos Mello's story appeared on Folha's front page four days in a row, and most other Brazilian newspapers, such as $O$ Globo, Estadão, and $A$ Tarde, reported extensively on the issue. A day after the scoop, Brazil's most-watched primetime TV news program Jornal Nacional devoted 9 of its 50 minutes to discuss the story by Campos Mello. The news story was immediately picked up by highly influential international press as well, including The Guardian (Phillips, 2018), Le Monde (Gatinois, 2018), and The New York Times (Isaac \& Roose, 2018). As Mello's reporting gained more attention and the high stakes became clear, candidates called upon the TSE and Federal Police to conduct a thorough investigation. ${ }^{13}$

The news coverage of the bulk messaging scandal generated immense public confusion and uncertainty regarding WhatsApp's role in the Brazilian elections. Although Mello's news investigation exposed the activities of marketing agencies and Bolsonaro's supporters in spreading political messages (and not WhatsApp itself), the TSE asked WhatsApp executives whether the company was responsible for the bulk messaging. WhatsApp responded by claiming Bolsonaro's campaign never paid the company for sponsored messages and confirmed that it had banned hundreds of thousands of Brazilian accounts for engaging in illegal practices connected to the election (Magalhães \& de Moraes, 2018). Bolsonaro, on the other hand, denied "controlling" the WhatsApp messaging effort (Maia, 2018). His supporters raced to defend him and created the hashtag "\#MARKETEIROSDOJAIR," a play on words that meant they (Bolsonaro's grassroots supporters) were the marketing agency responsible for his success. "We are Bolsonaro's robots" (Folha, 2018b), the supporters chanted and wrote on posters while campaigning in the streets (Figs. 13 and 14).

\footnotetext{
${ }^{13}$ Presidential candidate Haddad, for example, accused Bolsonaro of directly "creating a criminal organization with businessmen to send fake news against the Worker's Party (PT) campaign through the app WhatsApp" (Fonseca, 2018).
} 


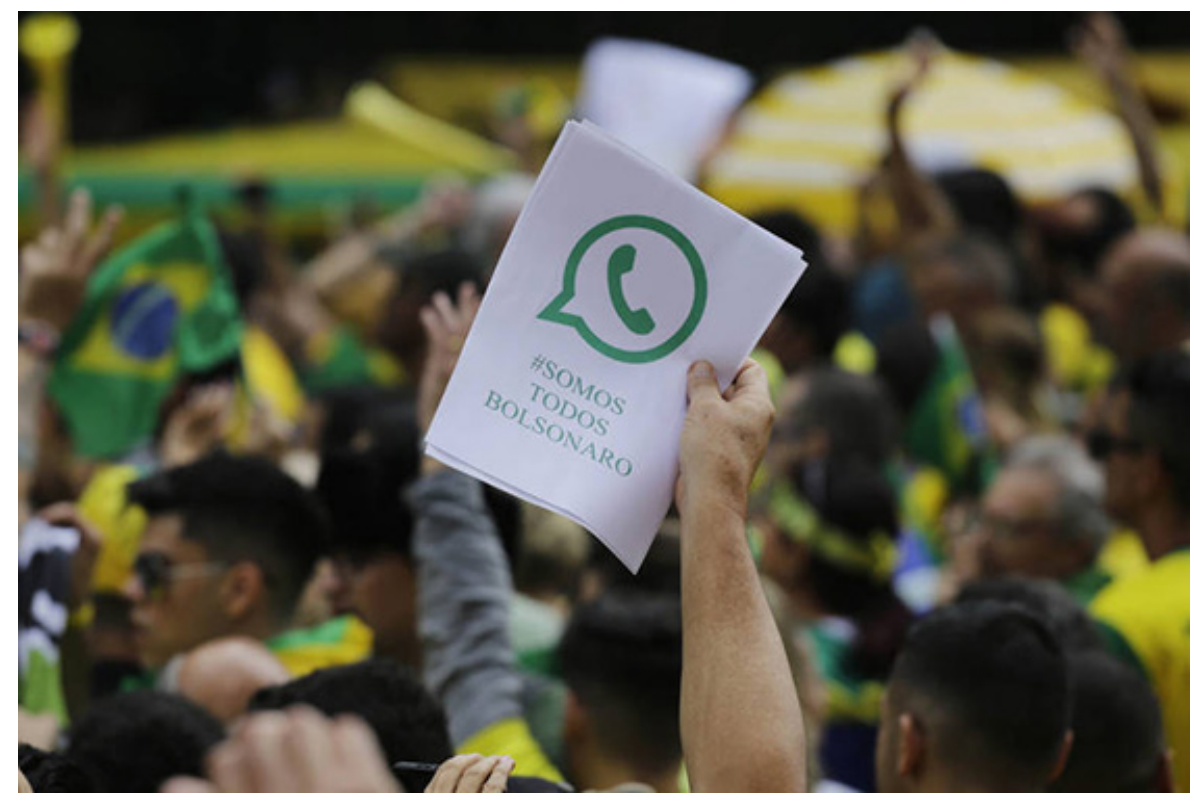

Fig. 13 - Demonstrators in the streets chanted and carried posters that said they were Bolsonaro's WhatsApp bots (in the image, “\#WeAreAllBolsonaro” alongside WhatsApp's $\log )$.

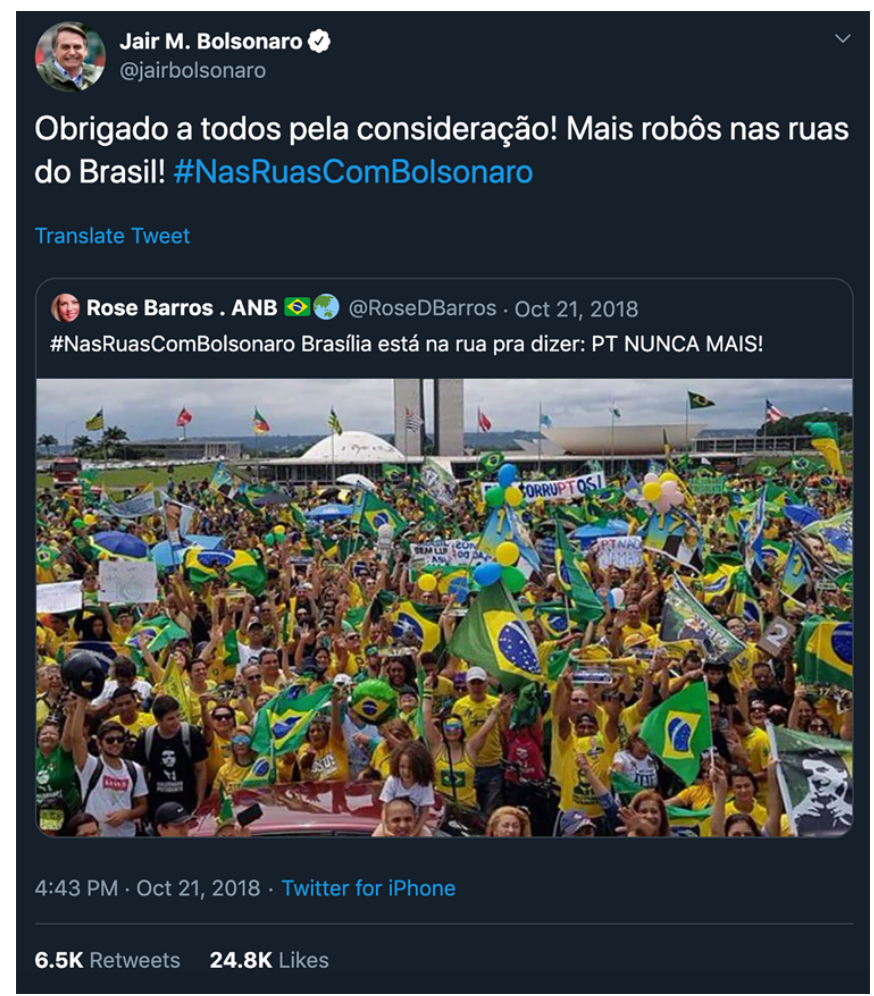

Fig. 14 - Bolsonaro tweeted, in response, saying "Thank you all for your consideration! More robots on the streets of Brazil! \#OnTheStreetsWithBolsonaro", alongside the image of a crowded demonstration. 
The fake news and bulk messaging scandals related to WhatsApp often became conflated in journalistic coverage, and led Brazilian publics and policymakers to question the utility and viability of the platform. One reporter described WhatsApp as an "unregulated electoral weapon" (Borges, 2018) that was illegally tipping the scales of the "virtual war" (Benites, 2018) happening via the app. These two major scandals, alongside many smaller ones beyond the scope of this article, positioned WhatsApp within a political battlefield in Brazil. The public crisis in confidence that formed through and around WhatsApp became a disruptive force and created a sociopolitical breakdown. Columnist Marcelo Leite (2018) claimed the platform played a crucial role in dividing and polarizing the country, writing "WhatsApp leads to the balkanization of the public sphere." Pundits argued WhatsApp was responsible for a "distortion factor" in politics and created an "Information apocalypse." TSE recognized WhatsApp regulation as a challenge, and members of the public interviewed by reporters contended the app "made the elections more confusing" (Rossi, 2018).

As our analysis of news media discourse suggests, these events led to a period of public questioning of WhatsApp in Brazil. News media insisted WhatsApp was a big player in the country's political polarization, and proclaimed it was a “"villain' or a 'hero' depending on who you ask" (Mena, 2018) and "mobilized voters-for good and evil" (Trisotto, 2018). This news media discourse highlights the fact that the platform became contested along ideological lines, as some users saw it as a legitimate space of political campaigning, while others considered it as a corrupt and problematic space. The situation prompted some users to opt out of the platform completely. Others critiqued its role in the elections and continued using it for other purposes. Brazilian news headlines captured the tensions: "Election rocks family and friends' groups on WhatsApp; read stories and tips on how to deal with disagreements" (Ortega, 2018) and "Tired of political debate? Learn how to leave and erase WhatsApp groups" (Padrão, 2018). A podcast created by Estadão offered advice: "How to reconcile families after the WhatsApp elections?" (Bomfim, 2018). As WhatsApp groups were politically hijacked during the election cycle, users started to consider the platform as a controversial and disputed territory, a space that could not be trusted.

Such press coverage incited discussions about the platform's affordances, and their relation to democratic practices. During the elections the TSE proposed eight changes to the platform in a meeting with WhatsApp representatives (Trindade, 2018). Academics and activists in Brazil also submitted recommendations, including reducing the number of times a message can be forwarded, limiting the size of new groups, and restricting broadcasts (Tardáguila, Benevenuto, \& Ortellado, 2018). WhatsApp responded by indicating it could not 
perform such brisk changes, and reinforced Vice President Chris Daniels' op-ed, which stated WhatsApp was already fighting misinformation by using "advanced technology" to detect spam (Daniels, 2018). In the end, the topic of proposing changes to WhatsApp became highly contentious in Brazil. While some advocated for Brazilian input on WhatsApp's structure, others attacked such moves claiming they would result in censorship of the platform (Constantino, 2019).

The sociopolitical breakdown of WhatsApp happened as scandalous and illegal practices-fake news and bulk messaging-infiltrated the platform and shaped the news media discourse. As WhatsApp became considered a "no man's land," the app's regulation and affordances also became contested subjects, and the public struggled to make sense of its disruptive capacities. This is particularly important as WhatsApp can be thought of as a platform-turned-infrastructure in Brazil. Yet since it is a privately-owned U.S. company, Brazil and its citizens have little power over WhatsApp's structure and operation. Therefore, invoking censorship and the "freedom of speech" to inoculate WhatsApp from accountability is troubling. It distracts attention away from the fact that US-owned digital platforms are exerting power over media and communication in the Global South contexts by offering infrastructures of everyday life that can be easily infiltrated by corrupt forces.

\section{Conclusion}

WhatsApp has been adopted by billions of people around the world, but there is still little known about the diverse ways that countries in the Global South negotiate its impacts on everyday life. To shed further understanding on WhatsApp in Brazil, we situated the app within the context of the country's emergent digital media conditions and, using content analysis, argued that the collective, cultural adoption of WhatsApp has transformed it from a mere messaging service app to a national media infrastructure used for individual and group, private, semi-private, and public communication. By critically examining Internet memes and news media discourses related to two WhatsApp disruptions during the 2015-2018 period, we demonstrate the increasingly important, if contentious, role of the platform in the country. In the Brazilian public imaginary and in everyday life WhatsApp is thought of and experienced as a national infrastructure, even if it is owned and controlled by Facebook, a largely unregulated global media conglomerate.

In the first case study, we argue that user-generated memes that circulated during the 2015-2016 technical shutdowns of WhatsApp serve as indicators of public sentiment about the 
app and its increasingly indispensable role in Brazilian everyday life. These sentiments imagine WhatsApp as an increasingly vital media and communication system. In the second case study, we analyzed news media content and suggested that WhatsApp's usage during the 2018 elections generated a sociopolitical breakdown, as election campaigns appropriated fake news and bulk messaging practices which led users to question WhatsApp's status. Press characterized WhatsApp as a space without regulation ("no man's land"), positioning it at the epicenter of the country's intensifying political polarization and pointing out the emergent frustration citizens-users felt in relation to the app and its operations.

Given our analysis, it is clear that "issues of platform expansion, regulation, and social consequences, which are current in the Euro-American public discourse" (Plantin \& deSeta, 2019) also need to consider more carefully how these platforms get appropriated, localized, experienced, and re-signified in the Global South. Without such considerations, scholars run the risk of reinforcing the hegemonic role these platforms play in the global media economy and ignoring important differences and critiques based on specific socio-historical conditions.

Building upon our two WhatsApp disruption case studies, we offer three points of discussion and then provide suggestions for further investigation. First, WhatsApp has transformed from a text-exchange mobile app into a national media infrastructure in Brazil, acquiring characteristics of "scale, ubiquity, and criticality of use" (Plantin \& deSeta, 2019, p.2; see also Plantin et al, 2018). Our focus on WhatsApp considered how its infrastructuralization has been defined by the country's socio-cultural usage of digital media, the rise of cheap mobile Internet, and the high-penetration of smartphones. This becomes particularly salient in Disruption \#1, when WhatsApp was shut down during 2015-2016, exposing the cultural, social, and affective relations with the platform as it became embedded in people's daily lives.

The fact that foreign, privately-owned platforms can become national media infrastructures in the Global South is consistent with neoliberalism in the global information economy. It is a direct result of the privatization of telecom infrastructure and the "'splintering" of the 'modern infrastructural ideal' of universal service delivered by monopoly providers" (Plantin et al, 2016: 306). Brazil, as many other countries, gave up on investing national/state funds to upgrade, strengthen and operate state-owned communication services, and instead saw the rise of WhatsApp and other imported digital platforms as the new norm.

Second, while WhatsApp has become adopted in Brazil a platform-turnedinfrastructure, the fact that it is not state-owned, but rather part of Facebook, Inc., owned and operated remotely from Silicon Valley, means that it cannot be directly controlled by the 
Brazilian state or its citizens. The mechanisms for regulation, legislation, and governance of WhatsApp are nuanced, contextual, and complex, making them feel far removed from Brazilian publics. The immense sociopolitical power of WhatsApp is best exemplified by illegal practices during the 2018 Brazilian elections (Disruption \#2). The news media discussion over the affordances of WhatsApp in that period points to how little accountability WhatsApp has to its users. Although removing the state from communications may be good for market forces or social activism, as other analyses have shown (Milan \& Barbosa, 2020; Johns, 2020) it also means that people, in Brazil and elsewhere, cannot look to their own governments to provide and regulate telecommunication services; rather, they must rely on an unregulated global, private conglomerate, Facebook, which owns WhatsApp. These conditions reveal new national/global media configurations that demand further investigation and analysis.

In both instances of disruption, WhatsApp refrained from taking any responsibility for communication circulated via its platform. As Gillespie (2010:359) suggests, companies frame themselves as "platforms" to "make claims about what these technologies are and are not, and what should and should not be expected of them." Like Facebook, WhatsApp insists it is not a content provider and thus bears little responsibility for communication on its platform. The company opportunistically frames the app as if it were a neutral communication tool. We argue, however, that WhatsApp in Brazil involves the complex entanglement of privatized, foreignowned, imported, and proprietary technology used for multiple modes of communication, and processes of Brazilian appropriation (legal and illegal) and negotiation (cultural and social aspects of use). As WhatsApp has become embedded in everyday life in Brazil, users have redefined the app's meanings and materialities.

Finally, WhatsApp's impact in Brazil became most intelligible to users/publics during instances of the app's disruptions. Both disruption cases studies demonstrate that users learned about and discussed their reliance on WhatsApp in self-reflexive ways, whether via memes circulated during court-ordered shutdowns or recognition of illegal messaging and political manipulation. By focusing on moments of infrastructural disruptions, it is possible to glimpse the sociotechnical imaginaries of users and diverse cultural nuances of these technologies as they are materialized in different global/national/local contexts. Crucial issues of disruption, breakdown, disruption, maintenance and repair (Jackson, 2014) are often eclipsed in digital media studies as scholars often focus on "novelty" and "innovation," or assume media systems typically operate "continuously" and "normally." Studying disruptions, whether technical shutdowns or sociopolitical breakdowns, as global phenomena emphasizes the importance of diverse national contexts, user experiences, media industries, and sociotechnical conditions the 
world and suggests the need for more scholarly and public literacy and knowledge about the integration of WhatsApp and other platforms in people's everyday lives in different parts of the world.

Further research could explore not only how other social media platforms such as WhatsApp are expanding into the Global South, but also how their affordances are transformed by forces of localization. This technological openness to local cultural variation should not be overlooked when trying to understand WhatsApp's successes and failures in Brazil and beyond. Future studies of platforms in other countries could consider the media histories that shape their usage, the telecom infrastructures that enable their functionality, the political systems in which they emerge, and the sociocultural conditions they penetrate.

While the international press coverage continues to raise concerns of Facebook as the "authoritarians' platform of choice" (Bennet, 2020), much less attention is given to its subsidiary WhatsApp, and the immense power it has in the Global South. After elected President in Brazil, far-right populist Bolsonaro said that "popular power does not need any more intermediaries," and pointed out that "new technologies" (such as WhatsApp) create a direct connection for people with their representatives (Brígido, 2018). This idealization of platforms-turned-infrastructures by populist politicians highlights the urgent need for critical assessments of the ways platforms get co-opted and appropriated as they circulate through the global economy. As these platforms reorganize media and communication across international contexts, their owners must be accountable for and responsive to the harms they enable in cultural and political spheres.

\section{References}

Allcott, H. \& Gentzkow, M. (2017) Social media and fake news in the 2016 election. Journal of economic perspectives, 31(2): 211-236.

Aouragh, M., \& Chakravartty, P. (2016). Infrastructures of empire: towards a critical geopolitics of media and information studies. Media, Culture \& Society, 38(4): 559575.

Baishya, A.K. (2015) \#NaMo: the political work of the selfie in the 2014 Indian general elections. International Journal of Communication, 9(2015): 1686-1700.

Baulch, E., Matamoros-Fernández, A. and Johns, A. (2020) "Introduction: Ten years of WhatsApp: The role of chat apps in the formation and mobilization of online publics", First Monday, 25(12). doi: 10.5210/fm.v25i12.10412.

Benites, A. (2018) "Nossos grupos combatem as notícias maldosas para desconstruir Bolsonaro". El País Brasil. Available at: https://brasil.elpais.com/brasil/2018/09/26/politica/1537998612 052780.html (accessed August 28, 2019) 
Bomfim, E. (2018) ESPECIAL: Como Reconciliar as Famílias Após as Eleições Do WhatsApp?" Estadão Podcasts. Available at: brasil.estadao.com.br/blogs/estadaopodcasts/especial-como-reconciliar-as-familias-apos-as-eleicoes-do-whatsapp/ (accessed March 10, 2019)

Borges, R. (2018) WhatsApp, uma arma eleitoral sem lei. El País Brasil. Available at: https://brasil.elpais.com/brasil/2018/10/18/tecnologia/1539899403_489473.html (accessed August 20, 2019)

Bowker, G.C. \& Star, S.L. (2000) Sorting Things Out: Classification and its Consequences. Cambridge: MIT Press.

Brígido, C. (2018) Bolsonaro promete governar 'sem distinção de origem, raça, sexo, cor ou religião'. O Globo. Available at: https://oglobo.globo.com/brasil/bolsonaro-prometegovernar-sem-distincao-de-origem-raca-sexo-cor-ou-religiao-23294805 (accessed August 22, 2019)

Campos Mello, P. (2018a) Documento Confirma Oferta Ilegal De Mensagens Por WhatsApp Na Eleição. Folha De S.Paulo. Available at: www1.folha.uol.com.br/poder/2018/10/documento-confirma-oferta-ilegal-demensagens-por-whatsapp-na-eleicao.shtml (accessed August 22, 2019)

Campos Mello, P. (2018b) Empresários bancam campanha contra o PT pelo WhatsApp. Folha De S.Paulo. Available at:

https://www1.folha.uol.com.br/poder/2018/10/empresarios-bancam-campanha-contrao-pt-pelo-whatsapp.shtml (accessed August 22, 2019)

Campos Mello, P. (2019a) Journalist Patrícia Campos Mello on WhatsApp and the 2018 Brazil Elections. Global Media Technologies and Cultures Lab. Available at: globalmedia.mit.edu/2019/05/01/patricia-campos-mello-interview/ (accessed August 28, 2019)

Campos Mello, P. (2019b) Empresas contrataram disparos pró-Bolsonaro no WhatsApp, diz espanhol. Folha De S.Paulo. Available at: https://www1.folha.uol.com.br/poder/2019/06/empresas-contrataram-disparos-probolsonaro-no-whatsapp-diz-espanhol.shtml (accessed August 22, 2019)

Cast Away. (2000). [DVD] Directed by R. Zemeckis. 20th Century Fox.

Constantino, R. Podcast Ideias: Por Que Intelectuais Querem Censurar O WhatsApp No Brasil? Gazeta Do Povo. Available at: https://www.gazetadopovo.com.br/rodrigoconstantino/artigos/podcast-ideias-por-que-intelectuais-querem-censurar-o-whatsappno-brasil// (accessed April 21, 2019)

Constine, J. (2018) WhatsApp Hits 1.5 Billion Monthly Users. \$19B? Not so Bad. TechCrunch. Available at: https://techcrunch.com/2018/01/31/whatsapp-hits-1-5billion-monthly-users-19b-not-so-bad/ (accessed January 31, 2018)

Cruz, F.B., Massaro, H., \& Borges, E. (2019) 'Santinhos', memes e correntes: um estudo exploratório sobre spams recebidos por WhatsApp durante as eleições. InternetLab. Available at: http://www.internetlab.org.br/wpcontent/uploads/2019/04/Relat\%C3\%B3rio-Spam-WhatsApp.pdf (accessed August 28, 2019)

Dahir, A. L. (2017) WhatsApp and Facebook Are Driving Kenya's Fake News Cycle. Quartz Africa. Available at: https://qz.com/africa/1033181/whatsapp-and-facebook-aredriving-kenyas-fake-news-cycle-ahead-of-august-elections/ (accessed November 07, 2018)

Daniels, C. (2018) Como O WhatsApp Combate a Desinformação No Brasil. Available at: https://www1.folha.uol.com.br/opiniao/2018/10/como-o-whatsapp-combate-adesinformacao-no-brasil.shtml (accessed April 21, 2019) 
de Oliveira, J.M. (2016) A infraestrutura tecnológica do setor de tecnologias da informação e comunicação no Brasil, in De Negri, F. \& Squeff, F.D.H.S. (eds) Sistemas Setoriais de Inovação e Infraestrutura de Pesquisa no Brasil, pp. 271-314. Brasília: IPEA.

de Souza, A. \& de Carvalho, J. (2018) Polícia Federal vai investigar uso de WhatsApp para fake news. O Globo. Available at: https://oglobo.globo.com/brasil/policia-federal-vaiinvestigar-uso-de-whatsapp-para-fake-news-23172204 (accessed August 28, 2019)

Domingos, R. (2018) É \#FAKE mensagem que diz que Bolsonaro simulou ser vítima de facada para disfarçar câncer. G1. Available at: https://g1.globo.com/fato-oufake/noticia/2018/10/17/e-fake-mensagem-que-diz-que-bolsonaro-simulou-ser-vitimade-facada-para-disfarcar-cancer.ghtml (accessed August 28, 2019)

dos Santos, J.G.B. (2019) Mobile networks and the Brazilian 2018 Presidential Election: From technological design to social appropriation. OU Brazil Studies Program OnePager, 2: 1-2.

Estadão. (2017) WhatsApp chega a 120 milhões de usuários no Brasil. Estadão. Available at: https://link.estadao.com.br/noticias/empresas, whatsapp-chega-a-120-milhoes-deusuarios-no-brasil,70001817647 (accessed August 20, 2019)

Farkas, J., Schou, J. (2018). Fake News as a Floating Signifier: Hegemony, Antagonism and the Politics of Falsehood. Journal of the European Institute for Communication and Culture, 25(3): 298-314.

Folha. (2018a) Só 4 Das 50 Imagens Mais Replicadas Na Eleição No WhatsApp São Verdadeiras. Folha De S.Paulo. Avaiable at: www1.folha.uol.com.br/poder/2018/10/so-4-das-50-imagens-mais-replicadas-naeleicao-no-whatsapp-sao-verdadeiras.shtml (accessed June 20, 2019)

Folha. (2018b) Atos a favor de Jair Bolsonaro ironizam suspeita de caixa dois. Folha De S.Paulo. Avaiable at: https://www1.folha.uol.com.br/poder/2018/10/atos-a-favor-dejair-bolsonaro-ironizam-suspeita-de-caixa-dois.shtml (accessed June 20, 2019)

Folha. (2019). Com crescimento digital, Folha lidera circulação total entre jornais brasileiros. Folha de S. Paulo. Available at: https://www1.folha.uol.com.br/poder/2019/04/comcrescimento-digital-folha-lidera-circulacao-total-entre-jornais-brasileiros.shtml (accessed August 28, 2019)

Fonseca, P. (2018) Haddad Acusa Bolsonaro De Criar Organização Criminosa Para Enviar Notícias Falsas Por WhatsApp. O Globo. Available at: https://oglobo.globo.com/economia/haddad-acusa-bolsonaro-de-criar-organizacaocriminosa-para-enviar-noticias-falsas-por-whatsapp-23164846 (accessed April 21, 2019)

G1. (2015) Telegram: Whatsapp bloqueado faz app ter mais 500 mil brasileiros em $3 \mathrm{~h}$. G1. Available at: http://g1.globo.com/tecnologia/noticia/2015/12/telegram-whatsappbloqueado-faz-app-ter-500-mil-novos-brasileiros-em-3-h.html (accessed August 10, 2019)

G1. (2016) Justiça manda bloquear WhatsApp, e internet responde com memes. G1. Available at: http://g1.globo.com/tecnologia/noticia/2016/07/justica-manda-bloquearwhatsapp-e-internet-responde-com-memes.html (accessed August 28, 2019)

Gatinois, C. (2018) Au Brésil, le Parti des travailleurs lance des poursuites contre les «fake news». Le Monde. Available at:

https://www.lemonde.fr/ameriques/article/2018/10/19/au-bresil-le-parti-destravailleurs-lance-des-poursuites-contre-les-fake-news 5371665 3222.html (accessed August 20, 2019)

Gillespie, T. (2010) The politics of 'platforms'. New Media \& Society, 12(3): 347-364.

Goel, V., Raj, S. \& Ravichandran, P. (2018) How WhatsApp Leads Mobs to Murder in India. The New York Times. Available at: 
https://www.nytimes.com/interactive/2018/07/18/technology/whatsapp-indiakillings.html (accessed November 07, 2018)

Gómez Cruz, E., \& Harindranath, R. (2020). WhatsApp as 'technology of life': Reframing research agendas. First Monday, 25(12). https://doi.org/10.5210/fm.v25i12.10405

Gragnani, J. (2018). Por que o Brasil se transformou em terreno fértil para a difusão de notícias falsas durante as eleições. BBC Brasil. Available at: https://www.bbc.com/portuguese/brasil-45978191 (accessed August 28, 2019)

Harbath, K. (2018) Protegendo as eleições no Brasil. FB Newsroom. Available at: https://br.newsroom.fb.com/news/2018/07/protegendo-as-eleicoes-no-brasil/ (accessed August 28, 2019)

Horst, H.A. (2011) Free, social, and inclusive: Appropriation and resistance of new media technologies in Brazil. International Journal of Communication, 5: 437-462.

Isaac, M., \& Roose, K. (2018) Disinformation Spreads on WhatsApp Ahead of Brazilian Election. The New York Times. Available at:

https://www.nytimes.com/2018/10/19/technology/whatsapp-brazil-presidentialelection.html (accessed August 20, 2019)

Isaac, M. (2016) WhatsApp Introduces End-to-End Encryption. The New York Times. Available at: https://www.nytimes.com/2016/04/06/technology/whatsapp-messagingservice-introduces-full-encryption.html (accessed April 15, 2019)

ITU. (2018a) Measuring the Information Society Report. Volume 1. Available at: https://www.itu.int/en/ITU-D/Statistics/Pages/publications/misr2018.aspx (accessed March 10, 2019)

ITU. (2018b) Percentage of Individuals Using the Internet. Statistics. Accessed March 10, 2019. https://www.itu.int/en/ITU-D/Statistics/Pages/stat/default.aspx (accessed March $10,2019)$

Jackson, S.J. (2014) Rethinking Repair. In Gillespie, T., Boczkowski, P.J. \& Foot, K.A. (eds) Media Technologies: Essays on Communication, Materiality, and Society, pp. 221-239. Cambridge: MIT Press.

Jamieson, K.H. (2018) Cyberwar: How Russian Hackers and Trolls Helped Elect a President. New York: Oxford University Press.

Jensen, M. (2011) Broadband in Brazil: A multipronged public sector approach to digital inclusion. World Bank, IFC, and InfoDev. Available at: http://documents.worldbank.org/curated/en/906401468338682300/Brazil-Broadbandin-Brazil-a-multipronged-public-sector-approach-to-digital-inclusion (accessed June 12, 2019).

Johns, A. (2020). 'This will be the WhatsApp election': Crypto-publics and digital citizenship in Malaysia's GE14 election. First Monday, 25(12). https://doi.org/10.5210/fm.v25i12.10381

Latinobarómetro. (2018) Informe Latinobarómetro 2018. Available at: http://www.latinobarometro.org/lat.jsp (accessed August 20, 2019)

Leite, M. (2018). Tortura De Verdade, Ou a Morte Lenta Da Opinião Pública. Folha De S.Paulo. Available at: www 1.folha.uol.com.br/colunas/marceloleite/2018/10/torturade-verdade-ou-a-morte-lenta-da-opiniao-publica.shtml (accessed June 20, 2019)

Lemos, R. \& Martini, P. (2010) LAN Houses: A new wave of digital inclusion in Brazil. Information Technologies \& International Development, 6(SE): 31-35.

Machado, C. \& Konopacki, M. Poder Computacional: Automação No Uso Do Whatsapp Nas Eleições. Instituto De Tecnologia e Sociedade do Rio de Janeiro (ITS-Rio). Available at: bibliotecadigital.tse.jus.br/xmlui/handle/bdtse/5550 (accessed August 20, 2019) 
Magalhães, V. \& de Moraes, M. (2018) 'Centenas De Milhares' De Contas Banidas. BR18. Available at: https://br18.com.br/centenas-de-milhares-de-contas-banidas/ (accessed April 21, 2019)

Maia, G. (2018) Não tenho controle se tem gente fazendo isso, diz Bolsonaro sobre WhatsApp. UOL. Available at: https://noticias.uol.com.br/politica/eleicoes/2018/noticias/2018/10/18/bolsonarofolha-whatsapp-empresarios.htm (accessed April 21, 2019)

Malka, V., Ariel, Y. \& Avidar, R. (2015) Fighting, worrying and sharing: Operation 'Protective Edge' as the first WhatsApp war. Media, War \& Conflict, 8(3): 329-344.

Matassi, M., Boczkowski, P.J. \& Mitchelstein, E. (2019) Domesticating WhatsApp: Family, friends, work, and study in everyday communication, New Media \& Society: 1-18.

Meirelles, F. (2018) 29a Pesquisa Anual do Uso de TI, FGV-EAESP-GVcia. Available at: https://eaesp.fgv.br/sites/eaesp.fgv.br/files/pesti2018gvciappt.pdf (accessed March 10, 2019)

Mena, F. (2018). Estratégia digital da campanha de Bolsonaro é uma jabuticaba, diz pesquisador. Folha de S. Paulo. Available at: https://www1.folha.uol.com.br/poder/2018/10/estrategia-digital-da-campanha-debolsonaro-e-uma-jabuticaba-diz-pesquisador.shtml (accessed August 28, 2019)

Milan, S., \& Barbosa, S. (2020). Enter the WhatsApper: Reinventing digital activism at the time of chat apps. First Monday, 25(12). https://doi.org/10.5210/fm.v25i12.10414

MobileTime. (2018) Panorama: Mensageria no Brasil. MobileTime \& OpinionBox. Available at:

https://www.infobip.com/assets/uploads/downloads/Mensageria_no_Brasil_Fevereiro de 2018.pdf (accessed August 28, 2019)

Molteni, M. (2018) When WhatsApp's Fake News Problem Threatens Public Health. Wired. Available at: https://www.wired.com/story/when-whatsapps-fake-news-problemthreatens-public-health (accessed November 07, 2018.)

Monnerat, A. (2018) Estadão Verifica chega ao fim das eleições com 107 mil mensagens no WhatsApp. Estadão. Available at: https://politica.estadao.com.br/blogs/estadaoverifica/estadao-verifica-chega-ao-fim-das-eleicoes-com-107-mil-mensagens-nowhatsapp/ (accessed August 20, 2019)

Moraes Moura, R. \& Pupo, A. (2018) Fachin Nega Pedido Do PSOL Para Reduzir Alcance De Mensagens Do WhatsApp. Estadão. Available at: https://politica.estadao.com.br/blogs/coluna-do-estadao/fachin-nega-pedido-do-psolpara-reduzir-alcance-de-mensagens-do-whatsapp/ (accessed April 21, 2019)

Nemer, D. (2016). Online favela: The use of social media by the marginalized in Brazil. Information Technology for Development, 22(3): 364-379.

Nemer, D. (2018) The Three Types of WhatsApp Users Getting Brazil's Jair Bolsonaro Elected. The Guardian. Available at: www.theguardian.com/world/2018/oct/25/brazilpresident-jair-bolsonaro-whatsapp-fake-news (accessed June 15, 2019)

Ortega, R. (2018) Eleição Abala Grupos De Amigos E Famílias No WhatsApp; Veja Histórias E Dicas Para Lidar Com Discórdias. G1. Available at: https://g1.globo.com/politica/eleicoes/2018/noticia/2018/10/04/eleicao-abala-gruposde-amigos-e-familias-no-whatsapp-veja-historias-e-dicas-para-lidar-comdiscordias.ghtml (accessed April 21, 2019)

Padrão, M. (2018) Cansou do debate político? Veja como sair e apagar grupos do WhatsApp. UOL. Available at: https://www.uol.com.br/tilt/noticias/redacao/2018/10/02/comosair-e-apagar-grupos-do-whatsapp.htm (accessed August 20, 2019)

Parks, L., \& Starosielski, N. (Eds.). (2015). Signal traffic: Critical studies of media infrastructures. Champaign: University of Illinois Press. 
Parks, L. (2012) Technostruggles and the satellite dish: A populist approach to infrastructure, in Bolin, G. (ed.) Cultural Technologies: The Shaping of Culture in Media and Society, pp. 76-96. New York: Routledge.

Parks, L. \& Mukherjee, R. (2017) From platform jumping to self-censorship: internet freedom, social media, and circumvention practices in Zambia. Communication and Critical/Cultural Studies, 14(3): 221-237.

Parks, L. \& Thompson, R. (forthcoming) The Slow Shutdown: Internet Regulation and Constraints Upon Online Content Creators in Tanzania, 2010-2018. International Journal of Communication.

Phillips, T. (2018) Bolsonaro business backers accused of illegal Whatsapp fake news campaign. The Guardian. Available at: https:/www.theguardian.com/world/2018/oct/18/brazil-jair-bolsonaro-whatsapp-fakenews-campaign (accessed August 20, 2019)

Plantin, J.-C., Lagoze, C., Edwards, P.N., Sandvig, C. (2018) Infrastructure studies meet platform studies in the age of Google and Facebook. New Media \& Society, 20(1): 293-310.

Plantin, J.-C. \& de Seta, G. (2019) WeChat as infrastructure: the techno-nationalist shaping of Chinese digital platforms. Chinese Journal of Communication, 12(3): 257-273.

R7. (2016) Internautas vão à loucura com bloqueio do WhatsApp e criam memes divertidos. R7. Available at: https://entretenimento.r7.com/pop/internautas-vao-a-loucura-combloqueio-do-whatsapp-e-criam-memes-divertidos-26082019 (accessed August 28, 2019)

Recuero, R. (2009) Social Media in South America: Orkut \& Brazil. Connected Learning Alliance. Available at: https://clalliance.org/blog/social-media-in-south-americaorkut-brazil/ (accessed April 15, 2019)

Resende, G. et al. (2019a) Analyzing Textual (Mis)Information Shared in WhatsApp Groups. Proceedings of the 10th ACM Conference on Web Science - WebSci '19, Boston, July.

Resende, G. et al. (2019b) (Mis)Information Dissemination in WhatsApp: Gathering, Analyzing and Countermeasures, paper presented at $W W W$ '19, San Francisco, May.

Resende, S. M. (2018) É Falsa Informação De Cartaz Sugerindo Que Haddad Vai Legalizar Pedofilia. Folha De S.Paulo. Available at: https://www1.folha.uol.com.br/poder/2018/10/e-falsa-informacao-de-cartazsugerindo-que-haddad-vai-legalizar-pedofilia.shtml (accessed April 21, 2019)

Rodrigues, U.M. (2019) Can Indian journalism survive the onslaught of social media. Global Media and Communication, 1-7.

Rossi, M. (2018) “O WhatsApp deixou as eleições mais confusas”. El País Brasil. Available at: https://brasil.elpais.com/brasil/2018/10/05/politica/1538772637 350727.html (accessed August 28, 2019)

Sandvig, C. (2013) The Internet as Infrastructure, in Dutton, W.H. (ed) The Oxford Handbook of Internet Studies, pp.86-106. Oxford: Oxford University Press.

Santos, M., Saldaña, M., \& Rosenberg, A. (2020). From access deprivation to skill acquisition: Cluster analysis of user behavior in face of a 12-hour legal blockage of WhatsApp in Brazil. First Monday, 25(12). https://doi.org/10.5210/fm.v25i12.10401

Santos, M. \& Faure, A. (2018) Affordance is Power: Contradictions Between Communicational and Technical Dimensions of WhatsApp's End-to-End Encryption. Social Media + Society, 4(3): 1-16.

Shifman, L. (2014) Memes in Digital Culture. Cambridge: MIT Press.

Spyer, J. (2017) Social Media in Emergent Brazil: How the Internet Affects Social Mobility. London: UCL Press. 
Star, S.L. \& Ruhleder, K. (1996) Steps toward an ecology of infrastructure: Design and access for large information spaces. Information Systems Research, 7(1): 111-134.

Talamoni, I. de C. \& Galina, S.V.R. (2014) Inovação no setor de tecnologia da informação e comunicação no Brasil-uma análise comparada entre indústria e serviço no período de 2001 a 2011. Navus-Revista de Gestão e Tecnologia, 4(2): 19-32.

Tardáguila, C., Benevenuto, F., \& Ortellado, P. (2018) Fake News Is Poisoning Brazilian Politics. WhatsApp Can Stop It. The New York Times. Available at: https://www.nytimes.com/2018/10/17/opinion/brazil-election-fake-newswhatsapp.html (accessed August 28, 2019)

Teixeira, T., Sabo, P.H. \& Sabo, I.C. (2017) Whatsapp and End-to-End Encryption: Legal Trend and the Conflict Privacy vs. Public Interest. Rev. Faculdade Direito Universidade Federal Minas Gerais, 71: 607-638.

Telebrasil. (2017) Preço Da Internet Móvel No Brasil Cai 18\% E é O Quarto Mais Barato Do Mundo." Telebrasil. Available at: http://www.telebrasil.org.br/sala-deimprensa/releases/8375-preco-da-internet-movel-no-brasil-cai-18-e-e-o-quarto-maisbarato-do-mundo (accessed April 16, 2019)

Telebrasil. (2019) O Desempenho Do Setor De Telecomunicações No Brasil - Séries Temporais. Telebrasil. Available at: http://www.telebrasil.org.br/panorama-dosetor/desempenho-do-setor (accessed March 10, 2019)

Tomazela, M. (2018) WhatsApp é Usado Para Dar Multa De Trânsito No Interior De SP. Estadão. Available at: https://sao-paulo.estadao.com.br/noticias/geral,whatsapp-eusado-para-dar-multa-de-transito-no-interior-de-sp,70002635070 (accessed December 17, 2018).

Treré, E. (2020). The banality of WhatsApp: On the everyday politics of backstage activism in Mexico and Spain. First Monday, 25(12). https://doi.org/10.5210/fm.v25i12.10404

Trindade, R. (2018) TSE Faz Oito Sugestões Para Que Mentiras Sejam Menos Espalhadas No WhatsApp. UOL Tecnologia. Available at: https://noticias.uol.com.br/tecnologia/noticias/redacao/2018/10/18/entenda-assugestoes-feitas-pelo-tse-para-consertar-o-whatsapp.htm (accessed April 21, 2019)

Trisotto, F. (2018) Como o WhatsApp Mobilizou Os Eleitores Brasileiros. Gazeta Do Povo. Available at: especiais.gazetadopovo.com.br/eleicoes/2018/como-o-whatsappmobilizou-os-eleitores-para-bem-e-para-mal/ (accessed March 10, 2019)

Vaidhyanathan, S. (2018) Antisocial Media: How Facebook Disconnects Us and Undermines Democracy. New York: Oxford University Press.

Vosoughi, S., Roy, D. \& Aral, S. (2018) The spread of true and false news online. Science, 359(6380): 1146-1151.

World Bank. (2019) Fixed Broadband Subscriptions (per 100 People), World Telecommunication/ICT Development Report and Database. WorldBank. Available at: https://data.worldbank.org/indicator/IT.NET.BBND.P2?end=2017\&locations=BRUS\&start $=1998 \&$ view $=$ chart $($ accessed March 10, 2019)

Zuckerberg, M. (2016) WhatsApp is now back online in Brazil! Facebook. Available at: https://www.facebook.com/zuck/posts/10102814103934951 (accessed August 20, 2019) 